Article

\title{
How Soil Ecological Intensification by Means of Cover Crops Affects Nitrogen Use Efficiency in Pepper Cultivation
}

\author{
Roberto Mancinelli $^{1}\left[\right.$, Rosario Muleo ${ }^{1}$, Sara Marinari ${ }^{2} \mathbb{D}$ and Emanuele Radicetti ${ }^{1, *}$ (D) \\ 1 Department of Agricultural and Forestry Sciences (DAFNE), University of Tuscia-Via S. Camillo De \\ Lellissnc, 01100 Viterbo, Italy; mancinel@unitus.it (Roberto Mancinelli); muleo@unitus.it (Rosario Muleo) \\ 2 Department for Innovation in Biological, Agro-Food and Forest System (DIBAF), University of Tuscia, \\ Via San Camillo de Lellissnc., 01100 Viterbo, Italy; marinari@unitus.it \\ * Correspondence: radicetti@unitus.it; Tel.: +39-0761-357556
}

Received: 21 May 2019; Accepted: 3 July 2019; Published: 7 July 2019

\begin{abstract}
Ecological intensification, based on agricultural practices that promote ecosystem services, has been recently proposed to match crop yield and environmental concerns. Two-year experiments were conducted in a Mediterranean environment. The treatments were: (i) four intensification levels (common vetch $(\mathrm{CV})$, ryegrass $(\mathrm{RG})$, bare soil without Nitrogen $(\mathrm{N})$ fertilization (Control-N0) and with $100 \mathrm{~kg} \mathrm{ha}^{-1}$ of $\mathrm{N}$ fertilization (Control-N100) applied during pepper cultivation), and(ii) two soil tillage [soil tillage at $15 \mathrm{~cm}$ and $30 \mathrm{~cm}$ of soil depth (ST-15 and ST-30, respectively)]. The field experiment was disposed in a randomized block design with three replications. Cover crop, soil samples, and pepper samples were collected for analysis. Soil available nitrogen increased after soil tillage, especially in $\mathrm{CV}$, which showed the highest fruit yield. The reduced soil $\mathrm{N}$ availability in RG decreased fruit yield and $\mathrm{N}$ uptake. The agro-physiological efficiency of pepper was similar in common vetch and Control-N100, while it was low in ryegrass. However, the adoption of RG increased the soil organic matter more than both control treatments, which, in turn, caused a depletion of soil organic matter. Moreover, reduced tillage practices for green manuring that both cover crops arepreferable to reduce external inputs in terms of fuel saving and farming operations.
\end{abstract}

Keywords: green manure; soil nitrogen; soil organic matter; nitrogen use efficiency; sweet pepper; sustainable agriculture

\section{Introduction}

Intensive practices under conventional agriculture by means of external inputs, such as crop breeding, water irrigation, and synthetic compoundadoption (i.e.,pesticides and inorganic fertilizers), have contributed to reducecrop yield limitations [1]. Among the synthetic compounds intensively used in the agricultural sector, nitrogen $(\mathrm{N})$ represents one of the most important factors that have allowed the intensification of agro-ecosystems to ensure crop productivity and stability for the growing global population [2]. Although the application of inorganic $\mathrm{N}$ fertilizers leads to increased crop yield and performance, their excessive application could determine several concerns related to environmental risks [3]. Inorganic forms of $\mathrm{N}$ are difficult to manage under field conditions because theycould be easily lost in the environment via leaching, denitrification, and volatilization processes [4,5]. Moreover, the combination of excessive application of inorganic $\mathrm{N}$ fertilizers with frequent and deep tillage operations is harmful for the agro-ecosystems in terms of reduced crop productivity, soil erosion,and water and air pollution [4]. These risks are particularly high in vegetable crops due to their higher added values of products compared to other field crops. Vegetable production systems characterized 
by large use of $\mathrm{N}$ fertilizers resulted in a reduced $\mathrm{N}$ use efficiency and high $\mathrm{N}$ loss in the environment via leaching and/or volatilization [5].

The main challenge of the modern agriculture is to feed the growing world population through the adoption of agronomical practices that are based on the adoption of renewable resources in order to reduce environmental risks due to the excessive use of synthetic inputs [6].

Recently, conservation agriculture based on minimum soil disturbance, permanent soil cover, and plant species diversification has been proposed worldwide as a sustainable farming system [7]. Although several research studiesreported that conservation agriculture practices are environmentally-friendly enhancesbiodiversity and biological processes $[8,9]$, uncertainty exists with respect to the impact of conservation tillage and nitrogen fertilizer application on the overall environment $[8,10,11]$.Furthermore, conservation practices could determine, in the long-term period, the establishment of perennial weeds are more competitive and difficult to manage [12]. Therefore, there is the need to combine intensive production systems based on high $\mathrm{N}$ use efficiency with reduced environmental impact [13].

Ecological intensification, based on the replacement of synthetic inputs with agricultural practices that promote and support ecosystem services, has been recently proposed to match increased yield levels and to mitigate the negative environmental impact of the conventional agriculture [1].

A possible solution to reach these objectives could be the inclusion of cover crops in rotation. Cover crops are plantspecies from different families (leguminous, cruciferous, and graminaceous) cultivated between two main crops that are not harvested, but left to grow during the fallow period to provide large numbers of ecological services in the agro-ecosystems during their growing period [14] and after their suppression $[15,16]$. Among the benefits provided by cover crop, there are improved weed management[17], increased $\mathrm{N}$ addition by atmospheric fixation (legume), or catching soil $\mathrm{N}$ (grass and cruciferous) [18] and reduce some plant adversities. Although there issome evidenceregarding the positive contribution and advantages of cover crop on agro-ecosystems [19], their inclusion in crop rotation is not widely practiced by farmers, especially in conventional tilled cropping systems, due to their thinking of the additional costs and labor $[1,20]$. Therefore, there is the need to improve the knowledge regarding the importance of cover crop inclusion in the vegetable cropping systems.

This study hypothesized that the adoption of cover crop as green manure could improve $\mathrm{N}$ use efficiency and fruit yield of pepper crop under a Mediterranean environment. The specific objectives of this study were to assess the effects of cover crops as green manure on: (i) total soil nitrogen availability during pepper cultivation, (ii) $\mathrm{N}$ use efficiency of pepper crop due to ecological intensification and soil tillage,and (iii) pepper crop yield.

\section{Materials and Methods}

\subsection{Research Area Characteristics and Experimental Design}

The research was carried out in 2003/2004 and 2004/2005 growing seasons at the experimental farm "NelloLupori" of the University of Tuscia (Viterbo). The experimental area is located in Central Italy approximately $80 \mathrm{~km}$ North of Rome $\left(45^{\circ} 25^{\prime} \mathrm{N}, 12^{\circ} 04^{\prime} \mathrm{E}\right.$, Alt. $310 \mathrm{~m}$ a.s.l.). The experiment was carried out in two adjacent fields in which barley (Hordeumvulgare L.) was previously grown. The treatments included in the experimental design were: (i) four intensification levels [common vetch (Vicia sativa L. Var. Topaze) cultivated before pepper crop (hereafter called CV),ryegrass (Loliummultiflorum Lam. Var. Elunaria) cultivated before pepper crop (hereafter called RG), bare soil without $\mathrm{N}$ fertilization during pepper cultivation (hereafter called Control-N0), and a bare soil fertilized with $100 \mathrm{~kg} \mathrm{ha}^{-1}$ of N during pepper cultivation (hereafter called Control-N100)],(ii) two tillage levels [soil tillage performed at $15 \mathrm{~cm}$ of soil depth with a rototiller in order to simulate minimum tillage (hereafter called ST-15) and soil tillage performed at $30 \mathrm{~cm}$ of soil depth with a mold-board plough and disked in order to simulate conventional tillage (hereafter called ST-30)]. Field experiment was arranged in a plot with36 $\mathrm{m}^{2}(6 \times 6 \mathrm{~m})$ size and disposed in a randomized block design with three replications. 
The climate is typical of the Mediterranean area with $760 \mathrm{~mm}$ annual precipitations, minimum temperatures slightly below $0{ }^{\circ} \mathrm{C}$ in winter (January and February), and maximum temperatures of about $36^{\circ} \mathrm{C}$ in the summer (July and August).

The soil of the experimental farm had homogeneous properties of volcanic origin classified as a Typic Xerofluvent [21]. Physicochemical characterization based on the official methods of analysis was performed in four soil samples collected in each of the three blocks, in order to verify the field homogeneity before the trials started. The textural class of the surface horizon $(0-30 \mathrm{~cm}$ depth) fell within the sandy-loam USDA classification, with $57 \%$ sand, $35 \%$ silt, and $8 \%$ clay. Moreover, the soil had $0.97 \%$ of total organic $\mathrm{C}$ and $0.12 \%$ of $\mathrm{N}$ content, $7.2 \mathrm{ofpH}\left(\mathrm{H}_{2} \mathrm{O}\right)$, a cation exchange capacity of $37.7 \mathrm{cmol} \mathrm{kg}^{-1}$, and a $525 \mu \mathrm{S} \mathrm{cm}{ }^{-1}$ electrical conductivity.

\subsection{Farming Operation Description}

In the late summer (September), the soil of the experimental area was ploughed up to $30 \mathrm{~cm}$ depth and fertilized with $90 \mathrm{~kg} \mathrm{P}_{2} \mathrm{O}_{5} \mathrm{ha}^{-1}$ as triple superphosphate before sowing the cover crops. The seed rates of the cover crops were of $50 \mathrm{~kg} \mathrm{ha}^{-1}$ for common vetch and $90 \mathrm{~kg} \mathrm{ha}^{-1}$ for ryegrass. They were sown early in the autumn (3 October, 2003 and 20 October, 2004, respectively). Both cover crops were left growing undisturbed during the winter and spring until May (31 May, 2004 and on 27 May, 2005 , respectively).Then they were cut with a straw chopper and incorporated into the soil using a mold-board plough to a depth of $30 \mathrm{~cm}$ and a rotary tiller to a depth of approximately $15 \mathrm{~cm}$ in order to simulate conventional deep soil tillage (ST-30) and minimum soil tillage (ST-15), respectively.The control plots (Control-N0 and control-N100) were kept bare during the cover crop growing cycle by mechanical weeding when weed seedlings started to emerge, as a common practice adopted in the area. Then, the soil was tilled at the same time to cover crop green manuring and as common practice adopted by the farmer for the transplanting bed preparation for pepper crop. After transplanting bed preparation, 1-month old seedlings of sweet yellow pepper crop, cv. F1 CLEOR, weretransplanted by hand on5 June, 2004 and on 3 June, 2005. The spatial arrangement of the crop was in single rows with $26.5 \mathrm{~cm}$ distance between plants within each row and $150 \mathrm{~cm}$ distance between rows, giving a plant density of 25,252 plants ha ${ }^{-1}$. The same set up of pepper management was adopted in all treatments. However, nitrogen fertilization was applied only in the Control-N100 treatment, which is the equivalent of $100 \mathrm{~kg} \mathrm{~N} \mathrm{ha}^{-1}$ applied by means of ammonium nitrate two times during the pepper cultivation. Moreover, during the cultivation period of sweet yellow pepper, four pest management applications of based copper product were applied against Phytophthora infestans (Mont.) de Bary. The sweet yellow pepper crop was drip irrigated to reintegrate the $90 \%$ of water lost through evapo-transpiration estimated by a class A pan evaporimeter and adjusted by crop coefficients during the growth cycle [22]. The dates of the field operations are reported in Table 1.

Table 1. Main field operations and sampling dates during the experiment.

\begin{tabular}{lcr}
\hline \multicolumn{2}{c}{ Growing Season } \\
\cline { 2 - 3 } & $\mathbf{2 0 0 3 / 2 0 0 4}$ & $\mathbf{2 0 0 4 / 2 0 0 5}$ \\
\hline Cover crop planting & 3 Oct, 2003 & 20 Oct, 2004 \\
Cover crop suppression & 31 May, 2004 & 27 May, 2005 \\
1st soil sampling * & 31 May, 2004 & 27 May, 2005 \\
Pepper transplanting & 5 Jun, 2004 & 3 Jun, 2005 \\
2ndsoil sampling * & 24 Jun, 2004 & 23 Jun, 2005 \\
1stN fertilization ** & 25 Jun, 2004 & 23 Jun, 2005 \\
3rdsoil sampling * & 21 Jul, 2004 & 18 Jul, 2005 \\
2ndN fertilization ** & 22 Jul, 2004 & 20 Jul, 2005 \\
4thsoil sampling * & 16 Aug, 2004 & 12 Aug, 2005 \\
5th soil sampling * & 9 Sep, 2004 & 6 Sep, 2005 \\
1stpepper harvesting & 16 Sep, 2004 & 7 Sep, 2005 \\
6thsoil sampling * & 7 Oct, 2004 & 4 Oct, 2005 \\
2ndpepper harvesting & 13 Oct, 2004 & 5 Oct, 2005 \\
\hline
\end{tabular}

* = measured performed in Common Vetch, Ryegrass, and Control-N0 treatments, ${ }^{* *}=$ Performed in Control-N100. 


\subsection{Cover Crops, Soil Sampling, and Vegetable Crop Sampling and Analysis}

In both years, samples of ryegrass and common vetch aboveground biomass were collected by hand-clipping the aboveground biomass inside a sampling quadrat of $0.5 \mathrm{~m}^{2}$ located in the central area of each plot before cover crop green manuring. The biomass samples were dried at $70{ }^{\circ} \mathrm{C}$ until constant weight in order to determine dry weight. After this, each sample was carefully ground for carbon and nitrogen content determination. The carbon content of the cover crop biomass was determined by oxidation with $\mathrm{K}_{2} \mathrm{Cr}_{2} \mathrm{O}_{7}$ at a temperature of $160^{\circ} \mathrm{C}$ [23], while total nitrogen of the biomass was determined by the Kjeldahl method.

Soil samples were collected in the no $\mathrm{N}$ fertilized plots (CV, RG, and Control-N0) starting from the soil tillage for bed preparation and performed every 30 days during the sweet yellow pepper growing period to determine the total soil available $\mathrm{N}$ variation among the treatments. Soil samples were collected at $0-30 \mathrm{~cm}$ depth, along the pepper rows between two consecutive plants. The air-dried soil samples were sieved $(<2 \mathrm{~mm})$ and kept at $4{ }^{\circ} \mathrm{C}$ until undergoing laboratory analysis. Available nitrogen was determined as ammonium and nitrate forms by colorimetric methods described by Baillie et al. [24] and Cataldo [25] after their extraction from the soil with $0.5 \mathrm{M} \mathrm{K}_{2} \mathrm{SO}_{4}$ and $1 \mathrm{M} \mathrm{KCl}$, respectively. Soil organic carbon (SOC) was determined in all treatments by oxidation with $\mathrm{K}_{2} \mathrm{Cr}_{2} \mathrm{O}_{7}$ at a temperature of $160{ }^{\circ} \mathrm{C}$ [23]. Soil $\mathrm{CO}_{2}$ flux was measured to evaluate the mineralization rate of cover crops from their green manuring until the final pepper harvesting. Soil $\mathrm{CO}_{2}$ emissions was monitored using EGM-4 (PP Sytems, Stofold, UK), which is a portable dynamic closed-chamber infrared gas analyzer system [26]. Measurements were taken in CV, RG, and Control-N0 treatments between 10:00 and 12:00 a.m. to avoid extreme heat fluxes. The measured $\mathrm{CO}_{2}$ emission suggested the net carbon mineralization value.

The sampling of sweet yellow pepper fruits was performed on 12 plants placed in the middle rows of each plot in both years. Fruits were sampled twice in order to meet the request of fresh sweet yellow pepper marketable. For each plot, fruit measurements concerned the number of marketable and unmarketable fruits and their fresh weight. Fifteen marketable fruits, from each plot, were randomly selected in order to measure the fruit size, wherethelength and diameter were determined. At the last harvesting, the plants were manually cut at soil surface level and dried at $70{ }^{\circ} \mathrm{C}$ together with their fruits until constant weight in order to determine the dry weight of total biomass. The nitrogen content of the dried straw and fruits was detected by the Kjeldahl method. The agro-physiological efficiency (APE) defined as the economic yield obtained per unit of nutrient adsorbed was calculated by using the formula suggested by Baligar et al. [27].

$$
\text { Agro }- \text { physiological ef ficiency }=\frac{[\text { Yield } F(\mathrm{~kg})-\text { Yield } \mathrm{C}(\mathrm{kg})]}{[\mathrm{N} \text { accumulation } F(\mathrm{~kg})-\mathrm{N} \text { accumulation in } \mathrm{C}(\mathrm{kg})]}
$$

where APE is the agro-physiological efficiency $\left(\mathrm{kg} \mathrm{kg}^{-1}\right), \mathrm{F}$ is the treatment that received the intensification, and $\mathrm{C}$ is the Control-NO.

\subsection{Data Analysis and Statistics}

Statistical analyses were performed using JMP statistical software package version 4.0 [28]. Differences in the cover crop, soil, and sweet yellow pepper parameters between the treatments were statistically analyzed by two-way ANOVA with repeated measurements over the two growing periods [28]. The means of each parameter were separated by least significance difference (LSD) at $p \leq 0.05$. The Bartlett test was performed to test the equal variance of the data. When necessary to homogenize the variance, the data were subjected to angular transformation before the variance analysis [29].Then the data reported in the tables were back transformed. Linear regressions were performed for selected variables using JMP statistical software package version 4.0 [28]. 


\section{Results and Discussion}

The weather measurements observed during the cover crop growing period reported a higher rainfall in 2003/2004 than in 2004/2005 (757.1 vs. $628.6 \mathrm{~mm}$, respectively), even if monthly deviations from the historical trend were observed in both growing periods (Figure 1). The total rainfall was similar to that observed in the last 30-year time span $(671 \mathrm{~mm})$. The mean temperature was comparable between the two cover crop growing periods (on average $9.8^{\circ} \mathrm{C}$ ), even though itwas lower than the historical data $\left(11.5^{\circ} \mathrm{C}\right)$. Based on these weather conditions, the emergence of ryegrass and common vetch cover crops was uniform in both periods about one week after their sowing. Despite the cover crop growing seasons beingregular, the aboveground biomass produced by both cover crop species was higher in $2004 / 2005$ when compared to $2003 / 2004$ (7.03 vs. $5.19 \mathrm{Mg} \mathrm{ha}^{-1}$ of dry matter (DM), respectively). This difference could be due to different weather condition, especially from March to May when the mean air temperatures were similar to the 30-year period and more favorable for cover crop growing in 2004/2005 (Figure 1). According to Sainju et al. [30], weather conditions significantly influence the germination, establishment, and growth of cover crop species. However, cover crops grown regularly until their suppression in May produced a similar quantity of aboveground biomass (6.12 $\mathrm{Mg} \mathrm{ha}^{-1}$ of DM). Both plant species were confirmed to be suitable for their utilization as cover crops in the Mediterranean environment providing several agro-ecological services [14].Among the benefits, common vetch, as a legume plant, reported higher nitrogen content in its tissues due to the ability to fix atmospheric $\mathrm{N}$ [31] compared to ryegrass $(1.90 \%$ vs. $0.56 \%$, respectively, Table 2$)$.Conversely, the $\mathrm{N}$ content in the ryegrass tissues was related to its catching ability.In fact, the grass species usually are able to immobilize the soil available nitrogen especially during the bare period [32]. Consequently, soil available nitrogen measured at cover crop green manuring was higher in CV treatment than in RG treatment (Figure 2). The soil available $\mathrm{N}$ tended to increase after cover crop green manuring, especially in common vetch treatment where the highest values was reached in both experimental years. Conversely, ryegrass green manure determined anincreasing soil available $\mathrm{N}$ trend, even if it was lower than CV treatments. The soil available $\mathrm{N}$ in control-N0 decreased slowly during the pepper cultivation period showing the lowest values at pepper harvesting (Figure 2). No significant differences were observed between ST-15 and ST-30 treatments $(p>0.05)$. It is well known that immediately after their incorporation into the soil, cover crop biomass rapidly mineralizes. Radicetti et al. [18] reported that organic residues coming from cover crops mineralize more than $50 \%$ of the total biomass in the first 30 days after the green manuring regardless of the soil tillage intensity. This microorganism-driven process determines the release of nitrogen that became available for the crop uptake. Thus, the soil inorganic $\mathrm{N}$ observed in the first period of pepper cultivation was a consequence of the rapid decomposition of organic residues [18]. Similarly, the difference between the experimental years was likely due to the highest quantity of cover crop biomass accumulated in 2004/2005, which released a high level of available nitrogen into the soil throughout the mineralization process. Moreover, the different rate of organic $\mathrm{N}$ mineralization was strongly related to $\mathrm{CO}_{2}$ emission, as observed in the relationship reported in Figure 3. Therefore, in the same environmental conditions, $\mathrm{CO}_{2}$ fluxes probably varied,according to the organic matter characteristics, such as $\mathrm{C}: \mathrm{N}$ ratio, as already reported by Radicetti et al. [18]. In fact, they were high in CV in both pepper growing seasons likelydue to the high $\mathrm{N}$ content in $\mathrm{CV}$ tissues and lower C:N ratio compared to $\mathrm{RG}$ tissues. The relationship between soil available $\mathrm{N}$ and monthly $\mathrm{CO}_{2}$ emission measured in Control-N0 was connected to the soil organic matter (SOM) mineralization process. Accordingly, the pepper harvesting showed a clear reduction of SOM in both conventional treatmentswas observed regardless of the soil tillage adopted. Conversely, the SOM balance was positive in CV and RG treatments with higher values in ST-15 than ST-30 (on average 0.024 vs. $-0.006 \%$, respectively, Table 3 ). Soil organic matter and the relative organic $\mathrm{C}$ and $\mathrm{N}$ fractions is an important topic for soil functionality.Therefore, preservingor enhancingthe SOM is an important goal for assuring a stable crop yield overthe long-term period [33]. Sainju et al. [34] reported that deep soil tillage boost mineralization of organic matter in the soil, whichcausesa depletion of soil fertility. 

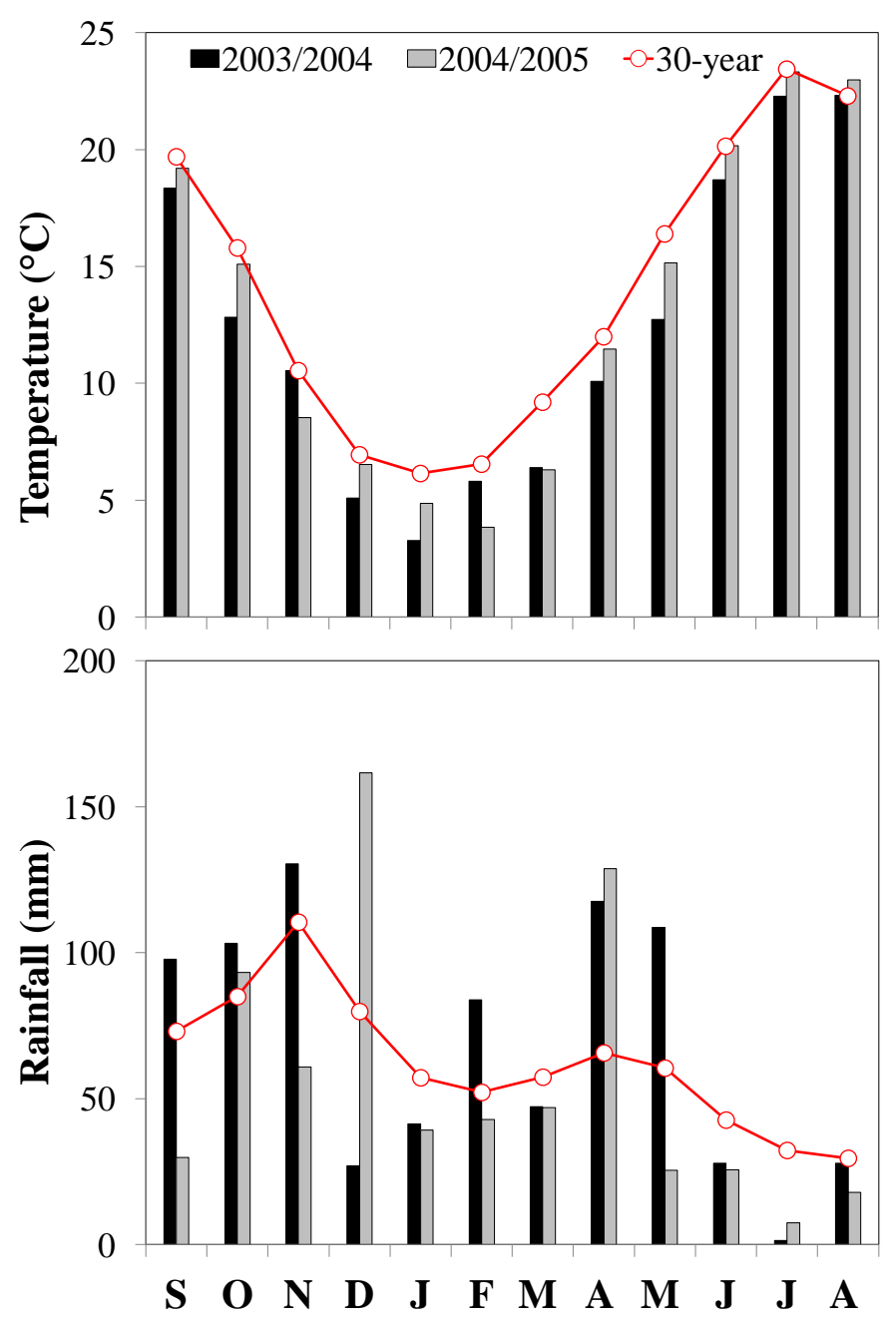

Figure 1. Rainfall and mean air temperature during the cover crop and pepper growing seasons in the two growing periods (2003/2004 and 2004/2005) with respect to average values overthe last 30-year period.

Table 2. The main effects of cover crops and growing period on the aboveground biomass and relative content of nitrogen $(\mathrm{N})$ and carbon $(\mathrm{C})$. Values belonging to the same variable followed by the same letter are not statistically different, according to LSD (0.05).

\begin{tabular}{lccc}
\hline & Aboveground Biomass & N Content & C Content \\
\cline { 2 - 4 } & $\mathbf{( M g ~ h a}^{-\mathbf{1}}$ & $\mathbf{( \% )}$ & $\mathbf{( \% )}$ \\
\hline Intensification Level & & & \\
\hline RG & $6.06 \mathrm{a}$ & $0.56 \mathrm{~b}$ & $42.86 \mathrm{~b}$ \\
CV & $6.17 \mathrm{a}$ & $1.90 \mathrm{a}$ & $49.99 \mathrm{a}$ \\
\hline Growing period & & & \\
\hline 2003/2004 & $5.19 \mathrm{~b}$ & $1.16 \mathrm{a}$ & $43.81 \mathrm{~b}$ \\
$2004 / 2005$ & $7.03 \mathrm{a}$ & $1.29 \mathrm{a}$ & $49.04 \mathrm{a}$ \\
\hline
\end{tabular}

$\mathrm{RG}=$ Ryegrass; $\mathrm{CV}=$ Common Vetch. 


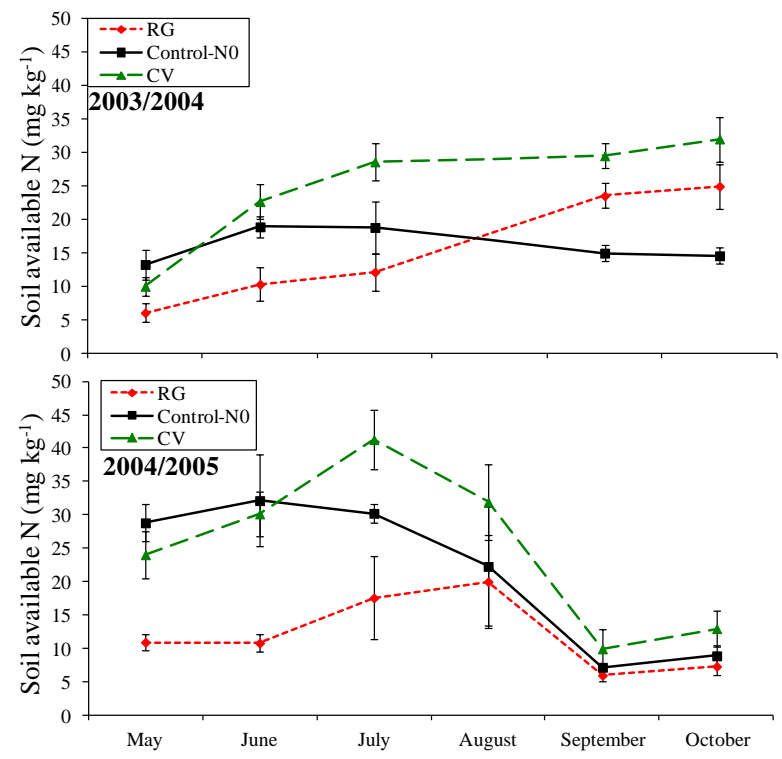

Figure 2. Soil available nitrogen measured during the pepper growing period in 2003/2004 and 2004/2005. Bars are standard errors $(n=3)$. RG = Ryegrass.CV = Common Vetch.

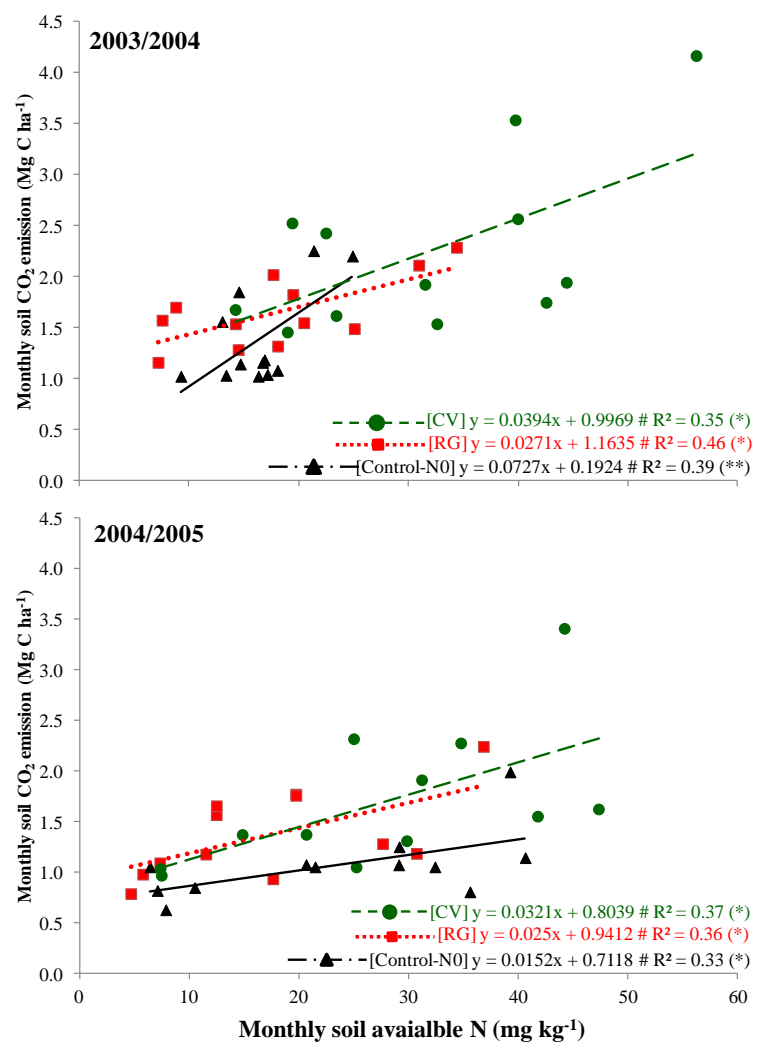

Figure 3. Soil available $\mathrm{N}$ plotted against soil $\mathrm{CO}_{2}$ emission for each month of two years in common vetch $(\mathrm{CV})$, ryegrass $(\mathrm{RG})$, and unfertilized control (Control-N0). The data fit with linear regression models. The significance level is $\left(^{*}\right)$ or $\left(^{* *}\right)$ at $P<0.05$ or $P<0.01$, respectively. 
Table 3. Soil organic matter and total nitrogen variations occurred after cover crop green manuring at pepper harvesting. The interaction between the two main factors are reported (intensification level $\times$ soil tillage). Values belonging to the characteristic and treatment with different letters are statistically different, according to LSD (0.05) in rows for soil tillage (upper-case letter) and in columns for the intensification level (lower-case letter).

\begin{tabular}{lcccc}
\hline \multirow{2}{*}{ Intensification Level } & \multicolumn{2}{c}{$\begin{array}{c}\text { STN Variation } \\
\text { (\%) }\end{array}$} & \multicolumn{2}{c}{$\begin{array}{c}\text { SOM Variation } \\
\text { (\%) }\end{array}$} \\
\cline { 2 - 5 } & ST-15 & ST-30 & ST-15 & ST-30 \\
\hline RG & $0.003 \mathrm{bA}$ & $0.002 \mathrm{aA}$ & $0.120 \mathrm{aA}$ & $0.067 \mathrm{aB}$ \\
CV & $0.021 \mathrm{aA}$ & $0.011 \mathrm{aA}$ & $0.104 \mathrm{aA}$ & $0.045 \mathrm{aB}$ \\
Control-N0 & $-0.034 \mathrm{cA}$ & $-0.022 \mathrm{cB}$ & $-0.030 \mathrm{bA}$ & $-0.044 \mathrm{bA}$ \\
Control-N100 & $-0.009 \mathrm{bA}$ & $-0.015 \mathrm{cA}$ & $-0.100 \mathrm{cA}$ & $-0.093 \mathrm{bA}$ \\
\hline
\end{tabular}

RG = Ryegrass. $\mathrm{CV}=$ Common Vetch. ST-15 = Soil tillage at $15 \mathrm{~cm}$ of soil depth. ST-30 = Soil tillage at $30 \mathrm{~cm}$ of soil depth. STN $=$ Soil total nitrogen. SOM = Soil organic matter.

Throughout the pepper cultivation, a scarce rainfall was observed during the summer period of both growing periods (on average $53.9 \mathrm{~mm}$ ) that corresponded to half of the rainfall measured in the 30-year period $(104.6 \mathrm{~mm})$. During the same period in 2005, the mean temperature detected was similar to the oneobserved in the 30-year data (on average $22.0^{\circ} \mathrm{C}$ ), while lower mean temperature was recorded in 2004 (on average $21.1^{\circ} \mathrm{C}$, Figure 1). The marketable pepper yield characteristics were similar in two pepper growing periods (2003/2004 and 2004/2005).They were generally highest in common vetch, which is similar to that of Control-N100 (Table 4). Previous studies have reported that crop fruit yield after green manuring of legume cover crop is comparable with the fruit yield of conventionally managed crop [16]. This effect is related to the ability of vetch residues to mineralize slowly and, thus, gradually supply nitrogen following the crop requirements. Conversely, the reduced soil $\mathrm{N}$ availability in RG and Control-N0 determined a reduced crop development with low marketable fruit yield and straw biomass production. No differences were detected between ST-15 and ST-30. Similarly, the nitrogen accumulation in the pepper fruit follows the same trend to the onedescribed in the fruit weight. The highest was in CV, intermediate in Control-N100, and the lowest in RG and Control-N0 (on average 111.65, 94.21, and $66.16 \mathrm{~kg} \mathrm{~N} \mathrm{ha}^{-1}$, respectively. See Table 5). Instead, the $\mathrm{N}$ accumulation in pepper straw was higher in CV and Control-N100 when compared to RG and Control-N0 (on average 90.14 vs. $66.22 \mathrm{~kg} \mathrm{~N} \mathrm{ha}^{-1}$, respectively). The $\mathrm{N}$ accumulation was similar at two tillage treatments in ST-15 and ST-30 (Table 5). Moreover, the nitrogen accumulation in pepper fruits was related in all ecological intensity treatments when compared to the SOM contentduringgreen manuring of cover crops (Figure 4). Generally, the pepper grown in the CV treatments accumulated more N in the fruits due to the high $\mathrm{N}$ content in the $\mathrm{CV}$ residues that are released into the soil throughout the mineralization process during the pepper growing period. According to Radicetti et al. [18], the mineralization of organic plant residues with high $\mathrm{N}$ content supply the nutrientcontinuously to the vegetable crop throughout its cultivation period, which determinesa high crop $\mathrm{N}$ uptake comparable to what is observed in the conventionally fertilized crop. As a consequence, the agro-physiological efficiency (APE) of pepper was similar to vetch and Control-N100, while it was low in ryegrass (on average 11.94 and $-16.24 \mathrm{~kg} \mathrm{~kg}^{-1}$, respectively. SeeTable 5). These results suggest that the ecological intensification by the adoption of common vetch may represent a suitable way to reduce the costs and the environmental impacts due to the use of inorganic $\mathrm{N}$ fertilizers [2]. Moreover, the benefits of legume cover crops, in terms of $\mathrm{N}$ availability and plant yield, positively affect the establishment, and grow the following winter vegetable, such as cabbage, which is cultivated in close rotation to the summer vegetable [15]. Conversely, the low $\mathrm{N}$ accumulation in ryegrass caused both low pepper $\mathrm{N}$ uptake and APE (Table 5). The inclusion of RG as a means of ecological intensification should be integrated with $\mathrm{N}$ fertilizers or cultivated in mixture with legume cover crop to avoid severe crop yield limitation [16]. 
Table 4. The main effect of growing periods, intensification level, and soil tillage on marketable fruit yield and yield characteristics of pepper crop. Values belonging to the same variable followed by the same letter are not statistically different, according to LSD (0.05).

\begin{tabular}{|c|c|c|c|c|c|c|}
\hline & \multicolumn{3}{|c|}{ Marketable Pepper Fruits } & \multicolumn{2}{|c|}{ Pepper Fruit Size } & \multirow{2}{*}{$\begin{array}{c}\text { Straw } \\
\text { Weight } \\
\left(\mathrm{Mg} \mathrm{ha}^{-1} \text { of DM) }\right.\end{array}$} \\
\hline & $\begin{array}{l}\text { Number } \\
\left(n . \mathrm{m}^{-2}\right)\end{array}$ & $\begin{array}{c}\text { Fresh Yield } \\
\left(\mathrm{Mg} \mathrm{ha}^{-1} \text { of FM) }\right.\end{array}$ & $\begin{array}{c}\text { Dry Yield } \\
\left(\mathrm{Mg} \mathrm{ha}^{-1} \text { of } \mathrm{DM}\right)\end{array}$ & $\begin{array}{l}\text { Length } \\
\text { (cm) }\end{array}$ & $\begin{array}{l}\text { Diameter } \\
\text { (cm) }\end{array}$ & \\
\hline \multicolumn{7}{|c|}{ Growing period } \\
\hline 2004 & $35.71 \mathrm{a}$ & $58.45 \mathrm{a}$ & $4,12 \mathrm{a}$ & $34.83 \mathrm{a}$ & $12.74 \mathrm{a}$ & $3.28 \mathrm{a}$ \\
\hline 2005 & $35.93 \mathrm{a}$ & $59.77 \mathrm{a}$ & $4,32 \mathrm{a}$ & $34.33 \mathrm{a}$ & $12.45 \mathrm{a}$ & $3.50 \mathrm{a}$ \\
\hline \multicolumn{7}{|l|}{$\begin{array}{l}\text { Intensification } \\
\text { level }\end{array}$} \\
\hline RG & $33.68 \mathrm{~b}$ & $54.31 \mathrm{~b}$ & $3.88 \mathrm{~b}$ & $34.94 \mathrm{a}$ & $12.59 \mathrm{a}$ & $3.09 \mathrm{c}$ \\
\hline $\mathrm{CV}$ & $39.31 \mathrm{a}$ & $63.15 \mathrm{a}$ & $4.67 \mathrm{a}$ & $35.38 \mathrm{a}$ & $12.87 \mathrm{a}$ & $4.06 \mathrm{a}$ \\
\hline Control-N0 & $31.59 \mathrm{~b}$ & $56.52 \mathrm{~b}$ & $3.87 \mathrm{~b}$ & $34.03 \mathrm{a}$ & $12.40 \mathrm{a}$ & $3.14 \mathrm{c}$ \\
\hline Control-N100 & $38.71 \mathrm{a}$ & $62.44 \mathrm{ab}$ & $4.46 \mathrm{ab}$ & $33.95 \mathrm{a}$ & $12.50 \mathrm{a}$ & $3.63 \mathrm{~b}$ \\
\hline \multicolumn{7}{|l|}{ Soil tillage } \\
\hline ST-15 & $36.30 \mathrm{a}$ & $58.29 \mathrm{a}$ & $4.27 \mathrm{a}$ & $34.43 \mathrm{a}$ & $12.69 \mathrm{a}$ & $3.58 \mathrm{a}$ \\
\hline ST-30 & $35.34 \mathrm{a}$ & $59.93 \mathrm{a}$ & $4.17 \mathrm{a}$ & $34.73 \mathrm{a}$ & $12.49 \mathrm{a}$ & $3.38 \mathrm{a}$ \\
\hline
\end{tabular}

RG = Ryegrass; CV = Common Vetch; ST-15 = Soil tillage at 15 of soil depth; ST-30 = Soil tillage at $30 \mathrm{~cm}$ of soil depth. $\mathrm{FM}=$ Fresh Matter; $\mathrm{DM}=$ Dry Matter.

Table 5. The main effect of growing periods, intensification level, and soil tillage on $\mathrm{N}$ accumulation in pepper fruits and straw, and agro-physiological efficiency of pepper crop. Values belonging to the same variable followed by the same letter are not statistically different, according to LSD (0.05).

\begin{tabular}{|c|c|c|c|}
\hline & \multicolumn{2}{|c|}{ Nitrogen Accumulation } & \multirow[b]{2}{*}{$\begin{array}{c}\mathrm{APE} \\
\left(\mathrm{kg} \mathrm{kg}^{-1}\right)\end{array}$} \\
\hline & $\begin{array}{c}\text { Fruits } \\
\left(\mathrm{kg} \mathrm{N} \mathrm{ha}^{-1}\right)\end{array}$ & $\begin{array}{c}\text { Straw } \\
\left(\mathrm{kg} \mathrm{N} \mathrm{ha}^{-1}\right)\end{array}$ & \\
\hline \multicolumn{4}{|l|}{ Growing period } \\
\hline $2003 / 2004$ & $81.74 \mathrm{a}$ & $76.86 \mathrm{a}$ & $2.58 \mathrm{a}$ \\
\hline $2004 / 2005$ & $87.34 \mathrm{a}$ & $79.49 \mathrm{a}$ & $2.51 \mathrm{a}$ \\
\hline \multicolumn{4}{|c|}{ Intensification level } \\
\hline RG & $63.49 \mathrm{c}$ & $66.08 \mathrm{~b}$ & $-16.24 \mathrm{~b}$ \\
\hline $\mathrm{CV}$ & $111.65 \mathrm{a}$ & $93.63 \mathrm{a}$ & $11.03 \mathrm{a}$ \\
\hline Control-N0 & $68.83 c$ & $66.35 \mathrm{~b}$ & - \\
\hline Control-N100 & $94.21 \mathrm{~b}$ & $86.65 \mathrm{a}$ & $12.85 \mathrm{a}$ \\
\hline \multicolumn{4}{|l|}{ Soil Tillage } \\
\hline ST-15 & $82.34 \mathrm{a}$ & $75.77 \mathrm{a}$ & $2.63 \mathrm{a}$ \\
\hline ST-30 & $86.74 \mathrm{a}$ & $80.58 \mathrm{a}$ & $2.46 \mathrm{a}$ \\
\hline
\end{tabular}

RG = Ryegrass; CV = Common Vetch; ST-15 = Soil tillage at 15 of soil depth; ST-30 = Soil tillage at $30 \mathrm{~cm}$ of soil depth; APE = Agro-physiological efficiency.

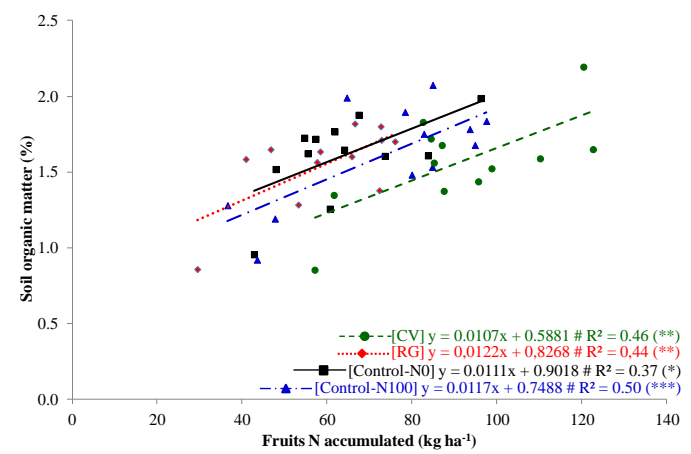

Figure 4. Soil organic matter at green manuring plotted against fruits $\mathrm{N}$ accumulated at pepper harvesting in common vetch (CV), ray grass (RG), control unfertilized (Control-N0), and control fertilized (Control-N100). The data fit with linear regression models. The significance level is $\left(^{*}\right),(* *)$ or $\left.{ }^{* * *}\right)$ at $P<0.05, P<0.01$ or $P<0.001$, respectively. 


\section{Conclusions}

The reduction of external inputs represents a priority in the modern and sustainable agriculture due to the growing concerns on food safety and environmental risks. The inclusion of cover crops in vegetable cropping systems as a part of ecological intensification strategy should be encouraged at the farm level for the provided agro-ecological services. The results reported supported the need to choose the cover crop species based on the benefits obtained from their specific adoption. In fact, legume cover crop, as common vetch, characterized by a high $\mathrm{N}$ content in its tissues, release nitrogen during the pepper cultivation period, which determines a high level of soil available nitrogen and, consequently, a vegetable fruit yield comparable to the conventional managed crop. Furthermore, the nitrogen supplied by the mineralization of common vetch residues seem to be more efficiently used by pepper crop with respect to that supplied by inorganic fertilizers. Conversely, the pepper yield observed in ryegrass suggests that an integration of inorganic $\mathrm{N}$ fertilizers is needed to reach a satisfactory marketable pepper yield. Although a reduced pepper yield was obtained afterapplying green manure, soil organic matter increased with respect to control treatments, which, in turn, caused a depletion of soil organic matter. Regarding the soil tillage, this study showed a similar effect between reduced tillage and conventional tillage in terms of pepper yield and soil available nitrogen, while an increase of soil organic matter was observed in reduced tillage. Based on these results, the reduced tillage applied for green manuring of both cover crops is preferable to diminish external inputs in terms of fuel saving and farming operation. In conclusion, ecological intensification by means of cover crops could be efficiently realized in the Mediterranean environment for the cultivation of different summer vegetable crops such as pepper, eggplant, tomato, and zucchini. However, further studies should be carried out toevaluate how to cover crop choice and their mixture could enhance various additional agro-ecological services such as contrasting the negative impact of climatic changes.

Author Contributions: Conceptualization, R.M. (Roberto Mancinelli) and E.R.; Methodology, R.M. (Roberto Mancinelli). Software, R.M. (Roberto Mancinelli); Validation, R.M. (Roberto Mancinelli), E.R., and R.M. (Rosario Muleo); Formal Analysis, R.M. (Roberto Mancinelli); Investigation, E.R., S.M., and P.P. Data Curation, Roberto Mancinelli (R.M.); Writing-Original Draft Preparation, R.M. (Roberto Mancinelli), E.R., R.M. (Rosario Muleo), S.M., and P.P.; Writing-Review \& Editing, R.M. (Roberto Mancinelli) and E.R. Supervision, R.M. (Roberto Mancinelli). All authors contributed to writing, discussing, and commenting on the manuscript.

Funding: This research received no external funding.

Acknowledgments: The research was partially supported by MIUR (Minister for Education, University and Research, Law 232/216, Department of Excellence). The authors would like to thank Claudio Stefanoni and FulviaGatti for the technical support forthe field experiments.

Conflicts of Interest: The authors declare no conflict of interest.

\section{References}

1. Wittwer, R.A.; Dorn, B.; Jossi, W.; Van Der Heijden, M.G.A. Cover crops support ecological intensification of arable cropping systems. Sci. Rep. 2017, 7, 41911. [CrossRef] [PubMed]

2. Hirel, B.; Tétu, T.; Lea, P.J.; Dubois, F. Improving Nitrogen Use Efficiency in Crops for Sustainable Agriculture. Sustainability 2011, 3, 1452-1485. [CrossRef]

3. Langeroodi, A.S.; Adewale Osipitan, O.; Radicetti, E. Benefits of sustainable management practices on mitigating greenhouse gas emissions in soybean crop (Glycine max). Sci. Total Environ. 2019, 660, $1593-1601$. [CrossRef] [PubMed]

4. Baggs, E.; Watson, C.; Rees, R. The fate of nitrogen from incorporated cover crop and green manure residues. Nutr. Cycl. Agroecosyst. 2000, 56, 153-163. [CrossRef]

5. Jackson, L.E. Fates and losses of nitrogen from a nitrogen-15-labeled cover crop in an intensively managed vegetable system. Soil Sci. Soc. Am. J. 2000, 64, 1404-1412. [CrossRef]

6. Agneessens, L.; De Waele, J.; De Neve, S. Review of Alternative Management Options of Vegetable Crop Residues to Reduce Nitrate Leaching in Intensive Vegetable Rotations. Agronomy 2014, 4, 529-555. [CrossRef]

7. Chauhan, B.S.; Singh, R.G.; Mahajan, G. Ecology and management of weeds under conservation agriculture: A review. Crop Prot. 2012, 38, 57-65. [CrossRef] 
8. Holland, J.M. The environmental consequences of adopting conservation tillage in Europe: Reviewing the evidence. Agric. Ecosyst. Environ. 2004, 103, 1-25. [CrossRef]

9. Hobbs, P.R. Conservation agriculture: What is it and why is it important for future sustainable food production? J. Agric. Sci. 2007, 145, 127-137. [CrossRef]

10. Pittelkow, C.M.; Liang, X.; Linquist, B.A.; van Groenigen, K.J.; Lee, J.; Lundy, M.E.; van Gestel, N.; Six, J.; Venterea, R.T.; van Kessel, C. Productivity limits and potentials of the principles of conservation agriculture. Nature 2014, 517, 365-368. [CrossRef]

11. Feng, Y.; Ning, T.; Li, Z.; Han, B. Effects of tillage practices and rate of nitrogen fertilization on crop yield and soil carbon and nitrogen. Plant Soil Environ. 2014, 60, 100-104. [CrossRef]

12. Campiglia, E.; Radicetti, E.; Mancinelli, R. Cover crops and mulches influence weed management and weed flora composition in strip-tilled tomato (Solanum lycopersicum). Weed Res. 2015, 4, 416-425. [CrossRef]

13. Bommarco, R.; Kleijn, D.; Potts, S.G. Ecological intensification: Harnessing ecosystem services for food security. Trends Ecol. Evol. 2013, 28, 230-238. [CrossRef] [PubMed]

14. Radicetti, E.; Osipitan, O.A.; Reza, A.; Langeroodi, S.; Marinari, S.; Mancinelli, R. $\mathrm{CO}_{2}$ Flux and C Balance due to the Replacement of Bare Soil with Agro-Ecological Service Crops in Mediterranean Environment. Agriculture 2019, 9, 13. [CrossRef]

15. Campiglia, E.; Mancinelli, R.; Di Felice, V.; Radicetti, E. Long-term residual effects of the management of cover crop biomass on soil nitrogen and yield of endive (Cichorium endivia L.) and savoy cabbage (Brassica oleracea var. sabauda). Soil Tillage Res. 2014, 139, 1-7. [CrossRef]

16. Campiglia, E.; Radicetti, E.; Brunetti, P.; Mancinelli, R. Do cover crop species and residue management play a leading role in pepper productivity? Sci. Hortic. 2014, 13, 97-104. [CrossRef]

17. Osipitan, O.A.; Dille, J.A.; Assefa, Y.; Radicetti, E.; Ayeni, A.; Knezevic, S.Z. Impact of cover crop management on level of weed suppression: A meta-analysis. Crop Sci. 2019, 59, 833-842. [CrossRef]

18. Radicetti, E.; Campiglia, E.; Marucci, A.; Mancinelli, R. How winter cover crops and tillage intensities affect nitrogen availability in eggplant. Nutr. Cycl. Agroecosyst. 2017, 108, 177-194. [CrossRef]

19. Schipanski, M.E.; Barbercheck, M.; Douglas, M.R.; Finney, D.M.; Haider, K.; Kaye, J.P.; Kemanian, A.R.; Mortensen, D.A.; Ryan, M.R.; Tooker, J.; et al. A framework for evaluating ecosystem services provided by cover crops in agroecosystems. Agric. Syst. 2014, 125, 12-22. [CrossRef]

20. Snapp, S.; Swinton, S.; Labarta, R. Evaluating cover crops for benefits, costs and performance within cropping system niches. Agron. J. 2005, 97, 322-332.

21. Soil Survey Staff Soil Survey Geographic (SSURGO) Database for [U.S.]. Available online: http://soildatamart. nrcs.usda.gov (accessed on 11 April 2019).

22. Allen, R.G.; Pereira, L.S.; Raes, D.; Smith, M. Crop evapotranspiration: Guidelines for computing crop requirements. Irrig. Drain. 1998, 300, D05109.

23. Springer, U.; Klee, J. Prüfung der Leistungsfähigkeit von einigen wichtigeren Verfahren zur Bestimmung des Kohlenstoffs mittels Chromschwefelsäure sowie Vorschlag einer neuen Schnellmethode. Zeitschrift für Pflanzenernährung Düngung Bodenkunde 1954, 64, 1-8. [CrossRef]

24. Baillie, I.C.; Anderson, J.M.; Ingram, J.S.I. Tropical Soil Biology and Fertility: A Handbook of Methods. J. Ecol. 1994, 157, 265. [CrossRef]

25. Cataldo, D.A.; Maroon, M.; Schrader, L.E.; Youngs, V.L. Rapid colorimetric determination of nitrate in plant tissue by nitration of salicylic acid. Commun. Soil Sci. Plant Anal. 1975, 6, 71-80. [CrossRef]

26. Pumpanen, J.; Ilvesniemi, H.; Hari, P. A Process-Based Model for Predicting Soil Carbon Dioxide Efflux and Concentration. Soil Sci. Soc. Am. J. 2003, 67, 402-413. [CrossRef]

27. Baligar, V.C.; Fageria, N.K.; He, Z.L. Nutrient use efficiency in plants. Commun. Soil Sci. Plant Anal. 2001, 32, 7-8. [CrossRef]

28. Anderson, A.J.B.; Cody, R.P.; Smith, J.K. Applied Statistics and the SAS Programming Language; Biometrics: Washington, DC, USA, 2006.

29. Gomez, K.A.; Gomez, A.A. Statistical Procedures for Agricultural Research; John Wiley \& Sons: Hoboken, NJ, USA, 1984.

30. Sainju, U.M.; Singh, B.P. Nitrogen storage with cover crops and nitrogen fertilization in tilled and nontilled soils. Agron. J. 2008, 100, 619-627. [CrossRef]

31. Anugroho, F.; Kitou, M.; Nagumo, F.; Kinjo, K.; Tokashiki, Y. Growth, nitrogen fixation, and nutrient uptake of hairy vetch as a cover crop in a subtropical region. Weed Biol. Manag. 2009, 9, 63-71. [CrossRef] 
32. Valkama, E.; Lemola, R.; Känkänen, H.; Turtola, E. Meta-analysis of the effects of undersown catch crops on nitrogen leaching loss and grain yields in the Nordic countries. Agric. Ecosyst. Environ. 2015, 203, 93-101. [CrossRef]

33. Sainju, U.M.; Whitehead, W.F.; Singh, B.P. Agricultural management practices to sustain crop yields and improve soil and environmental qualities. Sci. World J. 2003, 3, 768-789. [CrossRef]

34. Sainju, U.M.; Lenssen, A.W.; Caesar-TonThat, T.; Jabro, J.D.; Lartey, R.T.; Evans, R.G.; Allen, B.L. Dryland residue and soil organic matter as influenced by tillage, crop rotation, and cultural practice. Plant Soil 2010, 338, 27-41. [CrossRef]

(C) 2019 by the authors. Licensee MDPI, Basel, Switzerland. This article is an open access article distributed under the terms and conditions of the Creative Commons Attribution (CC BY) license (http://creativecommons.org/licenses/by/4.0/). 